\title{
Software Production in Kyrgyzstan: Potential Source of Economic Growth
}

\author{
Rahat Sabyrbekov (American University of Central Asia, Kyrgyzstan)
}

\begin{abstract}
In recent years, software development in the Kyrgyz Republic demonstrated $60-70 \%$ growth rate. Kyrgyz software products are exported to Central Asian neighbors and to the Western countries such as Italy, Australia and Holland. With the highest Internet penetration in the region and pool of qualified staff Kyrgyzstan has real chances to sustain the growth rate of the industry. Moreover, the cheap labor creates comparative advantage for local software producers. The break-up the Soviet Union lead to bankruptcies of traditional industries in the Kyrgyz Republic and thousands of highly qualified engineers were left unemployed. Simultaneously since independence Kyrgyz government implemented number of reforms to encourage development of Information and Communication Technologies which lead to the establishment of ICT infrastructure in the region.

The paper analyzes the development trend of the software production industry in the Kyrgyz Republic. We will also overview international experience as in the leading software producers as well as in neighboring countries. The study also builds projections for the next decade and draw on certain policy implications. In addition the paper will provide policy recommendations. The data used is from by the Association on IT companies, questionnaires, National Statistics Committee, Word Bank and Asian Development Bank.
\end{abstract}

JEL codes: F1, O34, O38

\section{Introduction}

Innovative economy, knowledge economy, information communication technology sector are probably most popular topics discussed in mass media and among politicians. There are tons of literature about structural changes in the economy and shift to the knowledge economy in new modern world.

The software industry is one of the main examples of knowledge economy, as the value of what a software company produces is almost entirely in the knowledge embodied in its products and services. However there are very few papers found on software production in the post-Soviet countries.

It is a fast growing industry producing high value services for its customers. The unique feature of the IT sector is indeed free access into the market and almost zero transportation costs due to Internet penetration.

Dynamic ICT growth in Kyrgyzstan along with positive or neutral government polices have established ground for software production. One of the distinct features is that $80 \%$ of the cost is labor, which is variable cost and labor of Kyrgyz software developers are lowest among main competitors.

\section{Software industry in developing countries and Kyrgyzstan}

The global software market had total revenue of \$198 billion in 2010 with compound growth of 5.4\% between 2006 and 2010. The performance of the market is forecast to accelerate with anticipation that the market in 2015 will have value of \$259.1 billion (Global Software Highlights, 2010).

Major suppliers and consumers of packaged software are in the developed countries. 


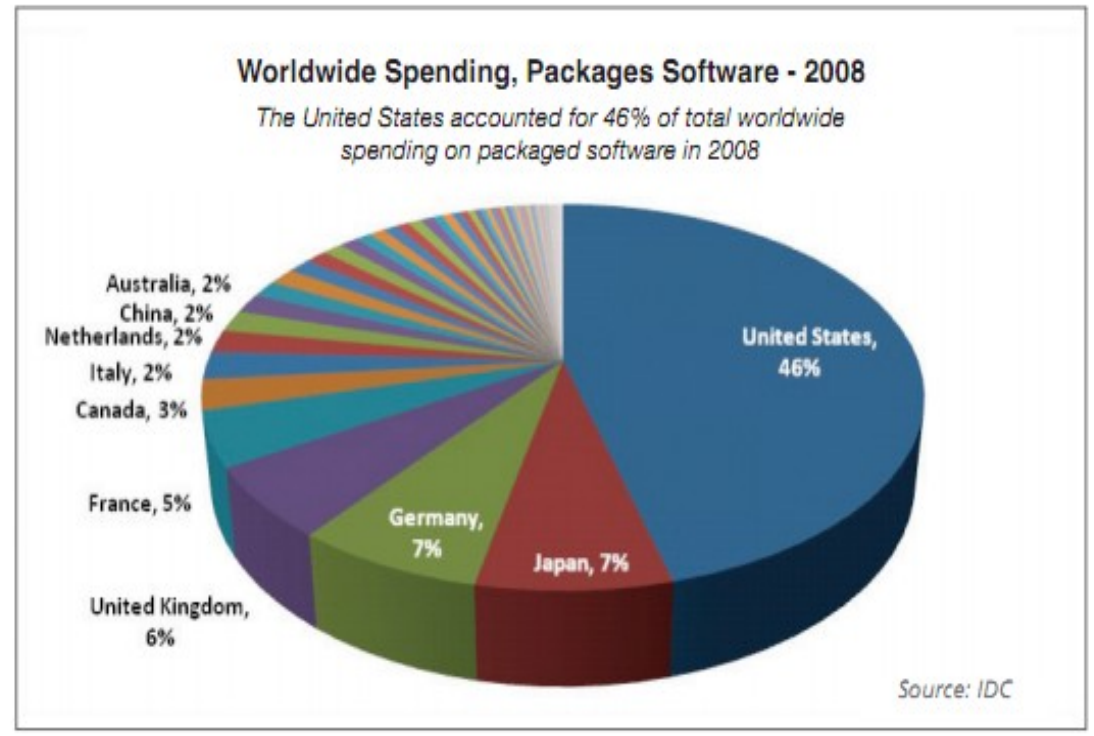

Figure 1. World spending of software, 2008. Source: International Data Corporation

Today companies from developing economies do not have significant share in the global software industry, but demonstrate fast growth. While companies from developing world are slow to become world leaders more and more software companies from the former Soviet bloc are emerging.

India has been the most successful among developing countries in establishing a major domestic computer software industry (Heeks, 1996; Bhatnagar and Madon, 1997). The Indian computer software industry has grown rapidly, in terms of its computer software and services trade. From virtually no exports in 1980, by 1994-1995 it had over \$160 million worth of exports and its rapid growth continues. Between 1990 and 1998 exports increased by over 50 per cent per year. This trend is expected to be sustained.

Since India achieved a major success in software industry policymakers in developing countries are paying close attention to the sector and Kyrgyzstan is no exception.

The case of India demonstrated that developing countries might have a piece of this lucrative market. The developing countries have an opportunity to compete with North due to lower input costs and the software production along with higher levels of ICT development offers developing economies an opportunity for economic growth (Costinot, 2008).

The break-up of the Soviet Union led to economic transformations in the Kyrgyz Republic. Once dominant and strategic sectors such as industrial and agricultural production lost their positions in favor of trade and services. However educational system was slow to change and technical institutes continued to produce engineers.

This coincided with IT-favored government policy. From the very first days of independence Kyrgyz government was keen on creating favorable conditions for ICT. In the early1998 the government adopted the National Strategy on ICT Development and since then the industry was left for self-development. However the IT sector grew and software production started to develop.

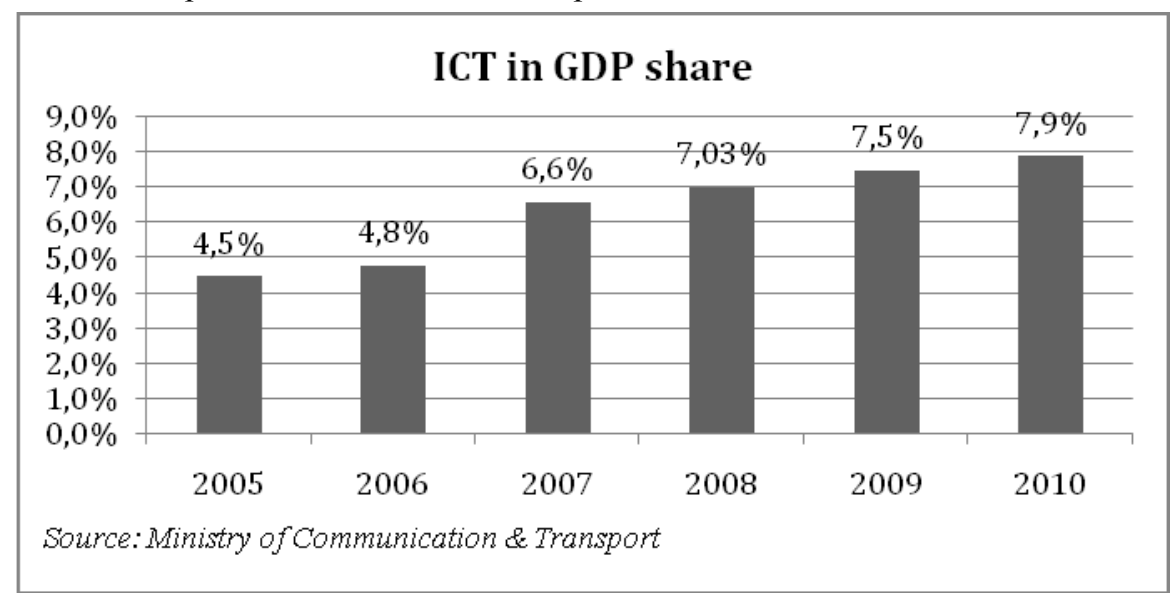

Figure 2. ICT share in GDP (2005-20010) Source: Ministry of Communication and Transport 
The data in Figure 2 demonstrates steady growth of ICT sector in the GDP. This growing trend confirms and creates favorable environment for the software production. Kyrgyzstan has developed fiber-optic network among major cities and has almost 100\% mobile Internet coverage. At the same time there are thirteen universities which produce IT specialists.

Presence of the reliable Internet connection and Internet penetration is another major condition for software development. Kyrgyzstan has the highest Internet penetration in the Central Asia (Table 1).

\begin{tabular}{|c|c|c|c|c|c|}
\hline ASIA & $\begin{array}{c}\text { Population } \\
\text { ( 2011 Est.) }\end{array}$ & $\begin{array}{c}\text { Internet } \\
\text { Users, } \\
\text { (Year } \\
\mathbf{2 0 0 0 )}\end{array}$ & $\begin{array}{c}\text { Internet } \\
\text { Users, } \\
\text { Latest } \\
\text { Data }\end{array}$ & $\begin{array}{c}\text { Penetration } \\
(\% \\
\text { Population) }\end{array}$ & $\begin{array}{c}\text { User } \\
\text { Growth } \\
(\mathbf{2 0 0 0 - 2 0 1 1 )})\end{array}$ \\
\hline Kazakhstan & $15,522,373$ & 70,000 & $5,300,000$ & $34.1 \%$ & $7,471.4 \%$ \\
\hline Kyrgyzstan & $5,587,443$ & 51,600 & $2,194,400$ & $39.3 \%$ & $4,152.7 \%$ \\
\hline Tajikistan & $7,627,200$ & 2,000 & 700,000 & $9.2 \%$ & $34,900.0 \%$ \\
\hline Uzbekistan & $28,128,600$ & 7,500 & $7,550,000$ & $26.8 \%$ & $100,566.7 \%$ \\
\hline
\end{tabular}

Table 1. Internet penetration, 2011 Source: Internet World Stats July 2011.

The data on the software industry is scarce. The most detailed and available data is from two surveys held by Kyrgyz Software and Service Developers Association (KSSDA) in 2008 and 2010 (KSSDA, 2008, 2010). KSSDA incorporates 13 large software-producing companies. The survey was in form of online anonymous questionnaire.

The intentional and unintentional public actions have lead to the establishment of significantly developed software production sector with strong export potential. Today according to Kyrgyz Software and Service Developers Association (KSSDA) the local software is exported not only to neighboring Kazakhstan but also to CIS and the European Union.

The available data suggests that there are about 30 companies which develop software and 100-200 freelancers. At the time when this paper was written GURU.COM - global leading freelancer finder - had portfolios of 39 Kyrgyz freelancers. The data suggests also that $60 \%$ of the companies who participated in the survey ( 21 companies) are engaged on export. Average number of employees per company is 18 . The biggest company employs - 45 people, smallest -7 .

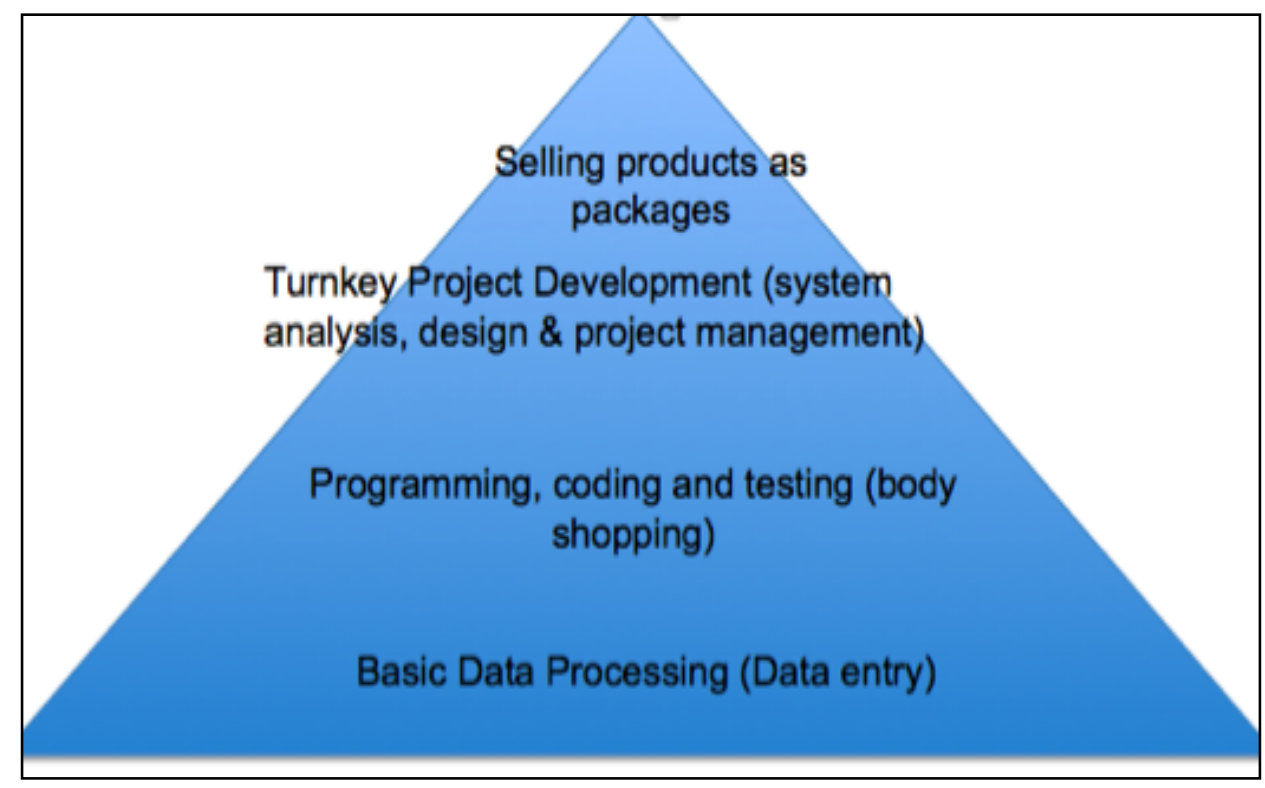

Figure 3. Value chain in software industry. Source: designed on the basis of software industry research

Based on the software production value chain majority of the Kyrgyz software developers are at the second and third steps. While very few companies are at the top producing software packages. The revenues of the individual companies range from $\$ 50000$ to more than $\$ 1$ mln.Exported software products include: ERP, HRMS, DMS, CRM, Web-applications and Mobile applications.

However there is a huge gap between government and private sector data on software export. Anonymous survey held by KSSDA show that the exports are about $\$ 10 \mathrm{mln}$ per year while National Statistics Committee show \$1.4 mln (National Statistics Committee, 2010). 


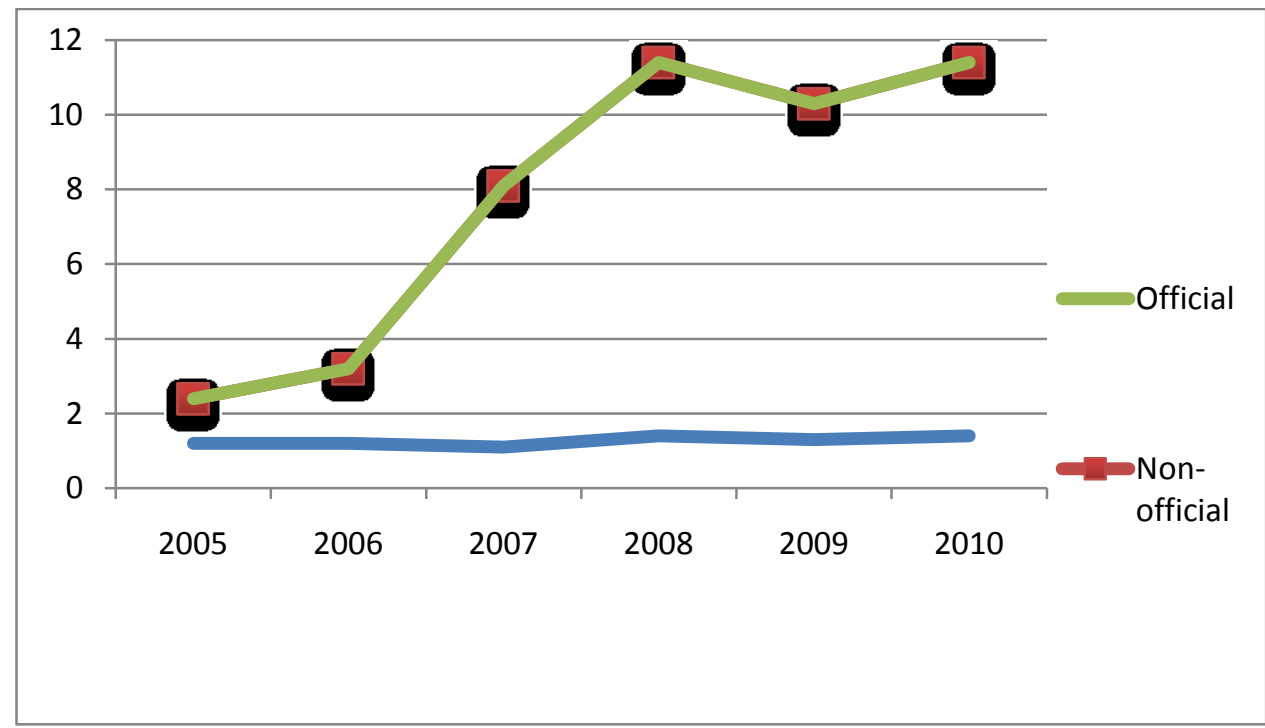

Figure 4. Official vs non-official export, (2005-2010, mln. USD) Source: Information and Communication Technologies in the Kyrgyz Republic 2006-2000 and KSSDA Report 2010

Figure 4 is comparison of the data provided by National Statistics Committee and independent association of software developers - KSSDA. We can notice that there is a huge difference between two lines. This suggests that most of the software producers work in shade economy. According to KSSDA survey $80 \%$ of software developers are not officially registered.

Kyrgyz software producers have comparative advantage. The cost of labor is much lower than in neighboring countries and there are no borders in software market. Thus all participants of the world market have equal access to the market. Another special feature of the software industry is that the main cost is the labor. Other inputs are relatively same which is even more flat in the region. The typical salary of the software engineer in Kyrgyzstan in 15-20 USD per hours while in Russia and Kazakhstan starts from 40USD per hour and in Western countries it starts from 50USD.

\begin{tabular}{|c|c|c|c|}
\hline Country & Wage per hour & $\begin{array}{c}\text { Average wage } \\
\text { per hour }\end{array}$ & $\begin{array}{c}\text { Cost of 100 hour product } \\
\text { (with average wage) }\end{array}$ \\
\hline Kyrgyzstan & $15-20$ & 17 & 1700 \\
\hline Kazakhstan & $30-40$ & 35 & 3500 \\
\hline Russia & $30-50$ & 40 & 4000 \\
\hline Western countries & $50-250$ & 150 & 15000 \\
\hline
\end{tabular}

Table 2: Comparative table of wages of software developers in USD (2011, USD) Source: calculated from various reports and surveys

The comparative advantage of Kyrgyzstan becomes clear if we use standard cost function: $Y=a+b x$

Where $Y$ is cost of production, $a$ - fixed cost, $b$ - variable cost of unit $x$. In order to compare the costs in the countries we will assume that $a$ is the same for all countries. Second assumption is that the cost function has only one variable - labor. Cost of labor in Kyrgyzstan is cheaper then in competing countries thus it creates the comparative advantage for Kyrgyz producers.

Apart from cheap labor Kyrgyz software sector also enjoys political support and share common language Russian. Today the development of Information Communication Technologies is still one of priorities for Kyrgyz government. In July 2011 the government adopted the Law on High Technologies Park. The law lowers the income tax for software developers down to $5 \%$ while nationwide it is $18 \%$ (Law on High-Tech Park, 2011). The law is designed to create a chain of software companies which will export its product and services. One of the most probable consequences of the law is "moving-out" of the companies from shade economy.

However one of the main criterions for the successful global scale software industry is investments from already established large software multinational corporations and thus the Kyrgyz government should establish more favorable conditions for welcoming international investors.

\section{Conclusion}

Most academic papers and government strategic policies are aimed at the development of traditional and well- 
studied sectors of economy. However this paper makes attempt to shed a light on new perspective industry. From the available data it is clear that the software industry is growing rapidly in Kyrgyzstan. High ICT development and pool of IT specialists along with government's non-interference policy created a fertile soil for software production. Proficiency in Russian language also can be attributed to the positive externalities for software production growth in Kyrgyzstan.

Despite the fragmented data the evidence of flourish innovative industry is seen. There are about 30 software producing companies which mainly work for the foreign partners.

Cost function analysis showed that labor is the heaviest cost in the software production and Kyrgyzstan has the lowest labor cost in comparison to neighbors. Moreover recent legislation creates new favorable conditions for software producers and it is expected that the industry will be legalized. The legalization of the industry will lead to higher visibility and attracting bigger international partners. It is also expected that the new legislation will lead to growth of local software market.

\section{References}

- Global Software Highlights, http://www.softwaretop100.org/global-software-top-100-edition-2010-thehighlights, 20 July 2010.

- Heeks, Richard, 1996. India's software industry: State policy, liberalization, and industrial development, New Delhi : Sage Publications.

- $\quad$ Bhatnagar S.C.; Madon S., 1997, "The Indian software industry: moving towards maturity. Journal of Information Technology”, Volume 12, Number 4, December 1997, pp. 277-288(12).

- Arnaud Costinot, 2009, “On the origins of comparative advantage”. Journal of International Economics, Volume 77, Issue 2, April 2009, Pages 255-264.

- $\quad$ Report of Kyrgyz Software and Service Developers Association, (KSSDA) 2008.

- Report of Kyrgyz Software and Service Developers Association (KSSDA), Promotank HQ 2010.

- Information and Communication Technologies in the Kyrgyz Republic 2005-2010, National Statistics Committee, 2010.

- Business finances of the Kyrgyz Republic 2006-2009, National Statistics Committee, 2010.

- $\quad$ Law on High-Tech Park, adopted by Jogorku Kenesh on 10 June of 2011. 